\title{
The Effect of Focus Group Discussions on Pre-service Teachers' Teaching Experiences and Practices: A Mixed Methods Study
}

\author{
Hasan Basri Memduhoğlu \\ Assoc. Prof., Department of Educational Science, Faculty of Education, Yuzuncu Yil \\ University, Turkey, hasanmemduhoglu@gmail.com
}

\section{Nihat Kotluk}

$\mathrm{PhD}$ candidate, corresponding author, Department of Curriculum and Instruction, Faculty of Education, Yuzuncu Yil University, Turkey, nihatkotluk@gmail.com

\section{Ahmet Yayla}

Asst. Prof., Department of Curriculum and Instruction, Faculty of Education, Yuzuncu

Yil University, Turkey, ahmetyayla33@gmail.com

The aim of this study is to investigate the effect of providing feedback to preservice teachers' (PSTs) through focus group discussion on PSTs' self-efficacy perception about teaching experiences and practices, to determine problems encountered during teaching practice by means of focus group discussion and to develop suggestions about solving these problems. This study was applied with 12 PSTs in two different schools during 12 weeks. Quantitative and qualitative data were gathered and analyzed. For quantitative data, non-parametric statistics and for qualitative data, descriptive analyses were used. As a result of the study, in experimental group, focus group discussion has significant and positive impact on PSTs' self-efficacy perception. Moreover, in interviews with PSTs, they stated that focus group discussion enabled them to make progress in topics such as lesson planning, classroom management, and teaching strategies.

Keywords: pre-service teachers (PSTs), focus group discussion, self-efficacy perception, teaching practices, feedback

\section{INTRODUCTION}

It is vital for the PSTs to carry out adequate level of practical work in the PSTs training process so that they can effectively put the theoretical knowledge they learn into practice in real education environments (Kocabaş, Durukafa, \& Gürses, 2000). In this context, in teacher training program (YÖK, 2007), which has been updated in Turkey in line with 
the opinions of practitioners and stakeholders and implemented from the 2006-2007 academic year, School Experience and Teaching Practice courses are being conducted.

Teaching practice is carried out in two academic terms in the classroom teacher education program and in one term in the other programs (YÖK, 2007). This course aims to enable candidate teachers to be able to develop teaching competences by teaching in classroom in public schools, understand the course program, evaluate the textbooks, carry out assessment and evaluation, and share the experiences gained during practice with his friends and application instructor (YÖK, 1998).

In teaching practice scheduled as eight hours per week, PSTs are expected to practice at least three hours of a six-hour school day under the supervision of teachers in these schools and make observations at other times. It is envisaged that during a two-hours course in the faculty a learning environment in which discussions and evaluations are made about the practices and course presentations in the schools will be designed (YÖK, 1998, Özkılıç, Bilgin, \& Kartal, 2008). Moreover, according to the guidelines related to the teaching practices, it is expected that PSTs make observations in the process, course work and evaluations about these processes (MEB, 1998).

When the studies related to teaching practices are examined (Küçükyılmaz, 2010, Yeşilyurt \& Semerci, 2011; (Şen, 2009; Kuran, 2009; Peker, 2009; Koç \& Y1ldız, 2012; Dallmer, 2004), it is clear that the studies focus more on such issues as effectiveness of teaching practices, problems experienced in practice, methodologies used in practice and classroom management. In these studies, it has been found out that the cooperation between the PSTs and the instructors and the teachers responsible for the application is incomplete, the PSTs are not actively involved in the process adequately, the application period is insufficient and feedback and corrective actions have not been made suitably. However, teaching practice process consists of observations made by the PSTs, course applications, feedback and evaluations, and weekly reports. In this context, it is important that discussions with PSTs are employed regarding their views on the process, the problems they encounter and the solutions of these problems, and thus, they should be given feedback.

It is necessary to conduct interviews and discussions with PSTs with the aim of giving feedback both on the observations obtained during the implementation of the process and on the practice itself. From this point of this study, the processes related to teaching practice that include highlighting discussions about both the observation / monitoring activities and the practice and also, giving them feedback are named as by the author of this study "observe-discuss and practice-discuss". In the course of observe-discuss and practice-discuss, in addition to the necessities and responsibilities in the directives, diaries and focus group discussions are included.

The determination of problems faced by PSTs in the practice process and provision of feedback to them by means of focus group discussions can contribute to not only solving these problems encountered in practice and to enhancing the beliefs of professional selfefficacy of them. High self-efficacy belief in the profession enables people in the field to become more effective and successful in their work. Teachers' high self-efficacy beliefs 
contribute positively to their ability to perform teaching effectively, to manage the class more effectively, to plan the course from beginning to end, and hence providing job satisfaction (Turcan, 2011). Therefore, in addition to providing a theoretical contribution to the field, this study has the potential to enable teacher training programs to be revised and updated and to provide practical contributions to decision-makers and practitioners in the training process, especially for PSTs, in order to make the teaching practice more effective. The overall objective of this study, in this regard, is; (1) to examine the effects of providing feedback to PSTs through focus group discussions on their self-efficacy beliefs, (2) to identify the problems encountered in teaching practice and to develop suggestions for solutions of these problems through focus group discussions. Accordingly, the following questions were tried to be answered in the study:

1. What is PSTs' self-efficacy perceptions level at the beginning of study?

2. Is there a significant difference between the self-efficacy perceptions of the control group and the experimental group to which the focus group discussions were applied at the end of the study?

3. During the process of teaching practice, what are the suggestions of PSTs about (a) planning, (b) ensuring student involvement, (c) instructional strategies, and (d) classroom management dimensions?

\section{METHOD}

In this study, experimental design was conducted as a quantitative approach and focus group discussions were used as qualitative approach. Of the experimental designs, Pretest post-test control group patterning was used as formulated in table 1.

Table 1

Randomized Pre-test - Post-test Control Group Design

\begin{tabular}{lllll}
\hline & Group & Pretest & Process & Posttest \\
\hline $\mathrm{R}$ & Experimental & $\mathrm{O} 1$ & focus group discussions & $\mathrm{O} 2$ \\
\hline $\mathrm{R}$ & Control & $\mathrm{O} 3$ & & $\mathrm{O} 4$ \\
\hline
\end{tabular}

Two groups are formed from the pool of candidates determined in experimental designs with pretest-posttest control groups. One of these is used as the experiment group and the other is used as the control group. In both groups pre-test and post-test measurements are applied. And the effect of the independent variable (focus group discussions) on the dependent variable (self-efficacy percepiton) is tested (Büyüköztürk, Çakmak, Akgün, Karadeniz, \& Demirel, 2013). In this study, for practice course, of the 12 teachers six PSTs were selected randomly in the experimental group, the other six were in the control group. In the experiment group, diaries were kept and focus group discussions were made during the teaching practice.

Focus group discussions that are applied in the qualitative aspect of the work are defined as the process of acquiring and producing in-depth information, where individuals can discuss ideas in a free environment through unstructured interviews and discussions with a small group. Focus group discussions, especially with groups of 6 to 12 participants, 
enable a discussion environment with previously prepared flexible questions on a predetermined topic (Krueger, 1994; Bowling, 2002). In this study, focus group discussions were conducted each week considering the problems faced by PSTs. For this purpose, the problems related to the categories formed as a result of the weekly analysis of the observation forms and the reflective diaries were discussed in the first, second, third and fourth focus group discussions with the PSTs in the experimental group and the opinions of the PSTs were recorded. At the end of observe-discuss and practice-discuss periods, the same questions were asked again to the PSTs in the general evaluation meeting held at the 11 th week.

\section{Study Group}

The study group consists of senior students from the Faculty of Education Physics Teaching Program of a state university in Turkey in the spring semester of 2014-2015 academic year. Five of these students are girls, seven boys. While six of them have teaching practice courses at Vocational High School and the other six continue teaching practices in Anatolian High School.

\section{Data Collection Tools}

Four separate data collection tools were used in the study:

Teacher self-efficacy scale. The original structure of the teacher self-efficacy scale used in this research was developed by Tschannen-Moran and Hoy (2001). The adaptation of the scale to Turkish and validity and reliability studies were carried out by Çapa, Çakıroğlu and Sarıkaya (2005). Self-efficacy scale consists of 24 items and three subscales. The first dimension called "providing student participation" is made up of the items about to what extent PSTs make students believe that they can do well in school tasks.

The second dimension, called "classroom management," is related to what extent to PSTs can control unwanted behaviors in the classroom. The third dimension, called "instructional strategies", consists of the items on to what extent PSTs can use different teaching and assessment strategies. In the adaptation study made by Çapa, Çakıroğlu and Sarikaya (2005), as a result of the analyses made to determine the reliability of the scale, the internal consistency coefficients calculated for each dimension were set as .82 for providing student participation, .84 for classroom management dimension, .86 for instructional strategy dimension, and .93 for the overall scale. As qualitative data collection tools, briefly described diaries, semi-structured observation forms, focus group discussions and semi-structured interviews were used.

Diaries. Diaries enable the PSTs to monitor and record the process and to actively participate in it by evaluating the data obtained, thereby raising the quality of learning (Dixon, 2009). The diaries help the PSTs ask questions and develop hypotheses (Lee, 2008), and think more deeply about the problems they encounter in the classroom environment (Ekiz, 2006). The diaries used in this study include (a) what the application teacher did / did not at the beginning, the development and the end of the course, and (b) 
what the practice teacher did / did not apply for the positive / negative situations in the class.

Semi-structured observation. These observations are made in the natural environment where behavior occurs (Karasar, 2005). In this study, PSTs used semi-structured observation form while observing in the classroom environment. This form consists of 10 questions developed by the researchers based on experts' opinion and a part in which the positive / negative situations that are experienced in the observation process can be noted down.

Semi-structured focus group interview form. This is a flexible form of interview that enables the interviewer to state personal views and to uncover the origins of the judgments (Karasar, 2005). In this study, semi-structured focus group interview form consisting of four questions developed by the researchers and PSTs was used.

\section{Application Process}

The study was conducted between February and May 2014 in 2 different schools with 12 PSTs for 12 weeks. Before applying the study, the experimental and control groups were determined randomly. Six of the 12 teachers in the experimental group were placed and the other six in the control group. At the beginning of the study, the self-efficacy scale was applied to experimental and control groups as pre-test. The implementation period of the study carried out by the experimental group is given in Table 2 . In the control group, the implementation process was conducted without focus group discussions, diaries, observation form.

Table 2

The implementation process of the study conducted with experimental group

\begin{tabular}{llll} 
1-2. week & $\begin{array}{l}\text { the application of pretest. } \\
\text { Introducing the school, and } \\
\text { meeting with students and teachers }\end{array}$ & $\begin{array}{l}\text { Information on how to fill in } \\
\text { diaries and semi-structured } \\
\text { observation forms }\end{array}$ & $\begin{array}{l}\text { Explanation of observe- } \\
\text { discuss and practice- } \\
\text { discuss process }\end{array}$ \\
\hline 3-4. week & $\begin{array}{l}\text { Observation of consultant teacher } \\
\text { of teaching practice }\end{array}$ & 1st focus group discussion & 1st. step of monitoring \\
\hline 5-6. week & the practice of courses by PSTs & 2nd. focus group discussion & 1st. step of monitoring \\
\hline 7-8. week & $\begin{array}{l}\text { Re-observation of consultant } \\
\text { teacher of teaching practice }\end{array}$ & 3rd. focus group discussion & 2nd. step of monitoring \\
\hline 9-10. week & the re-practice of courses by PSTs & 4th. focus group discussion & 2nd. step of monitoring \\
\hline 11. week & Applying post-tests & Overall assessment & Overall assessment \\
\hline 12. week & Semi-structured interviews & Semi-structured interviews & Semi-structured interviews \\
\hline
\end{tabular}

The implementation process by the researchers and PSTs is briefly described below.

\section{Studies made by PSTs}

PSTs made two types of observations in the process. According to this, after the first two weeks of general informing, they observed the practice teacher at 3rd 4th 7 th and 8 th week whereas they observed one of their friends who practiced the course at the 6th, 9th and 10th week. During these observations, the semi-structured observation/evaluation form was filled and diaries were kept. These observational records and diaries were taken into account in the focus group discussions, which were 
conducted at the later stages to return to teacher candidates on the implementation process.

\section{Studies made by researchers}

In order to more strongly emphasize the stages of the process named by the researchers of this study as "observe-discuss and practice-discuss" are briefly explained below.

\section{What is the process of observe-discuss and practice-discuss?}

The process of "observe-discuss and practice-discuss" is the method (named by the authors of this article) in which PSTs observe the practice teacher in the classroom, note down the observations of the practice in the classroom, they write the important points in the diary and discuss them in focus group discussions, and in which cooperation between PSTs, consultant teacher of teaching practice and assoc prof. is provided. The most important aspect of this process is focus group discussions. In this process, PSTs make observation for four weeks while they make teaching practice in courses for four weeks as stated in the guidelines. PSTs took down experiences / events/problems in class both during observations and practicing, and besides, they participated in the focus group discussions held every two weeks where the problems in the diaries and observation forms were discussed. The steps of the process are given in detail below:

\section{Observe-Discuss Stage}

This stage consists of the following steps: (a) PSTs have observed the practice teacher and noted their observations. (b) They wrote observation in their diary at the end of the school day and sent it to the assoc prof., (c) The assoc prof. has reviewed the diaries and observation forms. (d) After the assoc prof. examined the documents, he gathered the problems noted by PSTs in particular categories. (e) He made search of the relevant literature for the solutions of these problems and / or collected information from the experts concerned. (f) The identified problems and the proposed solution are discussed together with the PSTs in focus group discussions.

\section{Practice-Discuss Stage}

This stage consists of six steps: In the first step, one of the PSTs was teaching, meanwhile, the practice teacher and two other PSTs watched this process and wrote the experiences to the observation forms in the diary. In the second step, the PST, who made practice during the course, immediately sent the self-evaluation form and the completed diary to the instructor. The third, fourth, fifth, and sixth stages of the process are the same as the stages of observe-discuss.

\section{Analysis of the data}

\section{Quantitative Data Analysis}

Quantitative data of the study were analysed using descriptive statistics and nonparametric Mann-Whitney U test and Wilcoxon test. 


\section{Qualitative Data Analysis}

The Thematic Model (Miles \& Huberman, 1994) was used for qualitative data analysis. According to this model, the data obtained from the participants were placed in predefined themes in line with the purposes of the study. And then were supported by descriptive analysis. In interpreting the data, some views of PSTs were directly conveyed, thus giving the reader the opportunity to compare the findings obtained with the result (Demircioğlu, 2003). In the study, codes A1, A2 were used for the participants. Problems were examined under the following themes: "Problems of student participation", "Problems of classroom management", "Problems of teaching strategies", "Problems of planning", and "Other problems". The data analysis process is described in detail below.

First, four basic themes were defined, and the data obtained from the recorder and the interview forms were written in word on the computer. 37 sentences that were not considered relevant to the purpose of the study have been deleted by researchers among 224 sentences. The remaining sentences were numbered from 1 to 187 .

The researchers placed each sentence using the sequence number twice biweekly in predefined themes designed as Theme 1; Problems with planning, Theme 2; Problems with student participation, Theme 3; Problems about teaching strategies, Theme 4; Problems with classroom management. Table 3 and Table 4 show the number of different and similar opinions between the analyses and the number of opinions placed on themes as a result of the first and second analysis made by the researchers in line with this process.

Table 3

Number of opinions placed in the themes by the researchers in the 1st analysis and 2nd analysis

\begin{tabular}{lllllll}
\hline & Theme 1 & Theme 2 & Theme 3 & Theme 4 & Other & Total \\
\hline 1. Analysis & 37 & 41 & 51 & 40 & 18 & 187 \\
2. Analysis & 34 & 43 & 48 & 47 & 12 & 187 \\
\hline
\end{tabular}

Table 4

Number of similar and different opinions between the 1st and 2nd analyzes made by the researchers

\begin{tabular}{cccccccc}
\hline & & Theme 1 & Theme 2 & Theme 3 & Theme 4 & Other & Total \\
\hline Similarities & A1+A2 & 32 & 38 & 47 & 38 & 12 & 167 \\
\hline \multirow{2}{*}{ Differences } & A1 & 5 & 3 & 4 & 2 & 6 & 20 \\
& A2 & 2 & 5 & 1 & 9 & 0 & 17
\end{tabular}

The reliability of the research was determined by using the formula of Miles and Huberman (1994) (Reliability $=$ opinion association $/$ opinion association + opinion separation). This value was calculated as $82 \%$ for theme $1,82 \%$ for theme $2,90 \%$ for theme 3 , and $77 \%$ for theme 4 . When this ratio is over $70 \%$, it can be considered sufficient for the reliability of working (Miles \& Huberman's, 1994). In addition, in order to increase the internal consistency in the study, the opinions of the PSTs in the discussions and the opinions they stated at the overall evaluation meeting held at the end of the process were compared with each other. 


\section{FINDINGS}

The results of the study and research problems concerning the quantitative and qualitative data are presented separately below.

\section{The Quantitative Findings:}

\section{The Effect of Focus Group Discussions on PSTs' Self-Efficacy Beliefs}

The data obtained after the pre-tests were statistically analyzed by Mann-Whitney U test. The results obtained are shown in Table 5.

Table 5

Pre-test U-Test Results of Self Efficacy Perception by Groups

\begin{tabular}{lllllll}
\hline & Group & $\mathrm{n}$ & Mean & Total & $\mathrm{U}$ & $\mathrm{p}$ \\
\hline Providing Student & Experimental & 6 & 6.93 & 41.5 & 15.5 & .687 \\
Attainment (PSA) & Control & 6 & 6.08 & 36.5 & & \\
\hline Teacher's Teaching & Experimental & 6 & 7.33 & 44.0 & 13.0 & .419 \\
Strategies (TTS) & Control & 6 & 5.67 & 34.0 & & \\
\hline Classroom & Experimental & 6 & 6.58 & 39.5 & 17.5 & .936 \\
Management(CM) & Control & 6 & 6.42 & 38.5 & & \\
\hline Total & Experimental & 6 & 6.75 & 40.5 & 16.5 & .818 \\
& Control & 6 & 6.25 & 57.5 & & \\
\hline
\end{tabular}

As seen in Table 5, there was no significant difference between self-efficacy (teacher involvement, teaching strategies, classroom management) perceptions of PSTs in experimental and control groups before applying the study $(U=16.5, p<.05)$.

Wilcoxon test results about whether self-efficacy perceptions of PSTs show a significant difference before and after the teaching practice are given in Table 6 and 7.

Table 6

Wilcoxon Marked Rank Test Results of Control Group Pre-and Post-Study SelfEfficacy Perception Test Scores

\begin{tabular}{|c|c|c|c|c|c|}
\hline & Pretest-Posttest & Mean Rank & Rank Sum & $\mathrm{Z}$ & $\mathrm{p}$ \\
\hline PSApre- & Negative & 3.50 & 21.00 & 2.201 & $.028 *$ \\
\hline PSApost & Positive & 0.00 & 0.00 & & \\
\hline TTSpre- & Negative & 4.00 & 20.00 & 1.992 & $.046 *$ \\
\hline TTSpost & Positive & 1.00 & 1.00 & & \\
\hline CMpre- & Negative & 3.50 & 21.00 & 2.207 & $.027 *$ \\
\hline CMpost & Positive & 0.00 & 0.00 & & \\
\hline \multirow[t]{2}{*}{ Total } & Negative & 0.00 & 0.00 & 2.201 & $.028 *$ \\
\hline & Positive & 3.50 & 21.00 & & \\
\hline
\end{tabular}

* Based on negative sequences

As seen in Table 6, there is a significant difference in self-efficacy perceptions of PSTs in the control group between before and after the application of the study $(z=-2.201, p$ $<.05)$. According to this, PSTs' self-efficacy perceptions are higher in the post-test. 
Table 7

Wilcoxon Marked Rank Test Results of the Pre-Study and Post-Study Self-Efficacy Perceptions of the Experiment Groups

\begin{tabular}{|c|c|c|c|c|c|}
\hline & Pretest-Posttest & Mean Rank & Rank Sum & $\mathrm{Z}$ & $\mathrm{p}$ \\
\hline PSApre- & Negative & 3.50 & 21.00 & \multirow[t]{2}{*}{2.207} & \multirow[t]{2}{*}{$.027 *$} \\
\hline PSApost & Positive & 0.00 & 0.00 & & \\
\hline TTSpre- & Negative & 3.50 & 21.00 & \multirow[t]{2}{*}{2.214} & \multirow[t]{2}{*}{$.027 *$} \\
\hline TTSpost & Positive & 0.00 & 0.00 & & \\
\hline CMpre- & Negative & 3.50 & 21.00 & \multirow[t]{2}{*}{2.201} & \multirow[t]{2}{*}{$.028 *$} \\
\hline CMpost & Positive & 0.00 & 0.00 & & \\
\hline \multirow[t]{2}{*}{ Total } & Negative & 0.00 & 0.00 & \multirow[t]{2}{*}{2.201} & \multirow[t]{2}{*}{$.028 *$} \\
\hline & Positive & 3.50 & 21.00 & & \\
\hline
\end{tabular}

* Based on negative sequences

As Table 7 shows, there is a significant difference between pre- and post-test selfefficacy perceptions of the PSTss in the experimental group $(\mathrm{z}=-2.201, \mathrm{p}<.05)$. Accordingly, PSTs' self-efficacy perceptions of the in the experimental group are higher in the post-test.

The results of the Mann Whitney-U test on the difference of self-efficacy perceptions of the PSTs from each other in experimental and control groups are given in Table 8.

Table 8

Mann Whitney-U Test Related to Self-Efficacy Perceptions of PSTs According to Experiment and Control Groups

\begin{tabular}{lllllll}
\hline & Group & $\mathrm{n}$ & Mean Rank & Rank Sum & $\mathrm{U}$ & $\mathrm{p}$ \\
\hline PSA & Experiment & 6 & 8.42 & 50.5 & 6.5 & $.046^{*}$ \\
& Control & 6 & 4.58 & 27.5 & & \\
\hline TTS & Experiment & 6 & 9.25 & 55.5 & 1.5 & $.008^{*}$ \\
& Control & 6 & 3.75 & 22.5 & & \\
\hline CM & Experiment & 6 & 8.75 & 49.5 & 7.5 & .091 \\
& Control & 6 & 4.75 & 28.5 & 2.5 & $.009^{*}$ \\
\hline TOTAL & Experiment & 6 & 9.08 & 54.5 & 23.5 & \\
& Control & 6 & 3.92 & & & \\
\hline
\end{tabular}

$* \mathrm{p}<.05$

As shown in Table 8, there was a significant difference in favor of the experimental group between the self-efficacy perceptions of the PSTs in the experimental and control groups after the application of the study $(U=2.5, p<.05)$. According to this, the selfefficacy perceptions of the PSTs in the experimental group in which the focus group discussions were conducted for the purpose of feedback based on the kept diaries and observation records in the process of the teaching practice made in the schools, increased significantly compared to the PSTs the control group.

\section{The Qualitative Findings:}

\section{Problems Encountered in Teaching Practice}

Findings related to the problems encountered in teaching practice according to the determined themes are given below. 


\section{Problems related to planning}

In the focus group discussions, the question "Should a daily lesson plan be made, why?" were asked to the participant PSTs. All of the PSTs expressed the opinion that it is necessary to make a daily plan. However, detailed information about the reasons for preparing plan was not shared. However, it can be said that in the general evaluation meeting conducted as a result of the process, the PSTs experienced the problems arising from the day-to-day planning of teaching practices and after having discussed these problems in focus group discussions, they got aware of the importance of daily planning. An example of the PSTs' answers to this question is as follows:

"I did not do the daily lesson plan when I first started. I began to have difficulties. I started to make a daily plan after the suggestions about the daily plan in discussions (A2)."

PSTs did not express much thought in focus group discussions about the question, "How can a well prepared daily lesson plan be?" whereas they have presented different ideas about it in the overall evaluation meeting made at the end of the process. Some of them stated that the objectives of the course and the teaching methods and techniques to be used were well-prepared, others pointed to course plans where the content is found. Some PSTs' answers are as follows:

"Objectives and behaviors related to each course should be determined (A2).

"Content must be prepared well in a good lesson plan (A5)."

In the focus group discussions, the prospective teachers indicated that they had problems on the points such as ensuring the quietness of the class, drawing attention, communicating with the target, linking with previous topics, giving examples of daily life in relation to the question "How to plan the course entrance section in accordance with the introduction phase of the course". At the overall evaluation meeting held at the end of the process, there highlighted statements indicating that they have improved. An example of the PSTs' answers to this question is as follows:

"Generally, when I enter class I first maintain silence. Later, after a short summary of the previous lesson in the form of question and answer, I will start the lesson of that week (A4)'.

\section{Problems related to student participation}

In this category, PSTs were asked the question "What can be done to ensure that the students' attention is directed to the lesson in the course?". PSTs in the focus group discussions often point out that they feel themselves inadequate in this aspect. In the general evaluation made at the end of the process, all of the PSTs stated that they could draw students' attention and interest by telling a short story or something like joke style about the subject or by suddenly raising the voice tone or asking questions from their daily life. Some of the opinions expressed by the participants are as follows: 
"The 'silence effect' we developed in discussions came to my mind and I stopped telling the lecture at that moment and watched them silently. This state drew their attention and then everyone got silent (A1). "

While 3 of the PSTs in the focus group discussions did not answer this question about the question "What can be done to enable the students to be motivated by the lessons?", The other 3 PSTs stated that they could use grades to motivate the students. In the general evaluation meeting at the end of the process, 3 of the PSTs continued to indicate that grading was more effective. The other three candidates stated that cues, feedback and corrections could motivate the students. Some of the answers given by the candidates are as follows:

" When passing a second question, the students seemed more willing to solve the question in order to get highest grade (A5)."

"I gave him a few tips and he brought the rest himself. Throughout the course, he tried to answer questions in some ways (A1). "

In the focus group discussions regarding the question "How can you motivate students who are less interested in the course?", The PSTs indicated that in the class the practice teachers had as much difficulty as themselves, and some students were engaged in other things, and behaviors such as dismissing student from class as a solution were observed in general. At the end of the process, they used expressions such as dealing with students, giving reinforcement and giving responsibility. Some candidates' answers are as follows:

" I'll give him the feeling you're important to me. I try to help (A4). "

"I touched the shoulder of Deniz, I made eye contact with that student (A5)"

\section{Problems related to teaching strategies}

In this category, PSTs were first asked about the question "How well and how can you answer the difficult questions of the students?" The answers given to this question by the prospective teachers in the focus group discussions and at the general evaluation meeting at the end of the process were parallel. PSTs stated that they had a problem with the subject area. In focus group discussions, PSTs indicate that they try to hide it from students when they do not know the subject or question whereas in the general evaluation, the answers given by the candidates are as follows:

"I try to answer as possible as I can. If I have no idea, I say I forgot about the answer and will reply to the question later $(A 1)$. "

"If it is something I do not know, I say that I will investigate it (A4)."

In response to the question "How can you ensure that the lessons match the level of each student?", PSTs used general expressions such as " generally in accordance with medium level students" in the focus group discussions whereas the answers given at the general evaluation meeting at the end of the process seem to include the names of some 
theories, methods and techniques generally found in the field. Some of the answers given by the candidates are as follows:

"I lectured according to the theory of multiple intelligences we discussed in discussions (A3)."

To the question "Are you able to apply different teaching methods in classrooms?", Prospective teachers replied that they were theoretically aware of different teaching methods, but did not apply them, by giving similar responses both in focus group discussions and at general evaluation at the end of the process.

" I know different teaching methods. But I use the straight method (A3). "

\section{Problems related to classroom management}

In this category, in response to the asked question "How can you control the behaviors that affect the lesson negatively", the PSTs, in the focus group discussions generally indicated that they get nervous, they threaten students with grades, they raise the tone of voice and sometimes they want help from the practice teacher, however, in the general evaluations made at the end of the process, they stated that they tried to use different techniques such as eye contact, time of silence with the effect of focus group discussions. Some of the answers given by the candidates are as follows:

"I first made eye contact. After he had been silent for a while, he went on the same act and so I approached and touched his shoulder (A5)."

" Girls talked among themselves and did not listen to the lesson. Then I used 'Ilanguage' we mentioned in discussions and I said that when you do it I feel very sorry and they really kept silent (A6)."

In response to the question "How can you ensure that pupils comply with classroom rules?", In the focus group discussions, PSTs often stated that they reminded them of the rules and warned them strictly. But, some candidates in the general evaluations made at the end of the process have stated that they have decided the rules together with students and that they are trying to develop mutual understanding while some candidates stated that they still continued to warn students. One of the answers given by the candidates is as follows:

"We reminded the students of the rules and made them obey the rules (A6)."

When responding to the question "How should the tone of voice in classroom management be used?", in focus group discussions, the PSTs reported that they were excited in the class and they yelled at them to control the course because they have for the first time experienced the process. Yet, they expressed different views at the overall evaluations made at the end of the process. Some of the answers given by the candidates are as follows:

"The sound of the tone of the class must be well adjusted. The same tone bores the student (Al)." 
"Successful teacher, like a theatre artist, should adjust the tone of voice well (A2)."

\section{Other issues}

There are also some problems that PSTs have experienced in the process. However, only one issue (A1) in accordance with the authorization given to the problem can be stated as follows:

"One of the students kept telling me that he always thought of me and said that his ex-girlfriend looked like me and wrote me a love poem. Actually, I had no idea what to do about it. But after the incident, I learned in focus group discussions that in such situations I should ignore it, otherwise he would repeat this behavior $\operatorname{again}(A 1)$,'

Finally in the study, in interviews with each of the PSTs, when the expressions of PSTs are taken into account, all of the PSTs have stated that they have benefited from many aspects of their process observe-discuss and practice-discuss and that in the following years, this method should be carried out with PSTs. Candidates' opinions are as follows:

"We discussed in focus group discussions how we should treat our students and how to handle the lesson (A5)."

" In short, this study was an opportunity for us to criticize ourselves (A1). "

"In discussions, I learned some information that I knew was wrong and corrected them (A2)."

" At first we had trouble, but over time it was improved by the group discussions (A4)."

"When we applied what we talked about, it was effective (A6). "

"I feel I have made progress (A3). "

\section{DISCUSSION AND CONCLUSION}

The feedback, which is one of the basic elements of the communication process, is the factor that makes the difference between "transmission" and "communication". While the transmission expresses a one-way flow from source to receiver, the feedback transforms the communication from the correct transmission to a two-way process. Thus, the feedback adds to the communication process the cyclicality and continuity. As a process, education begins with communication first. In education, feedback complements the two-way mutual communication process between the teacher and the learner (teacher-student). In this regard, feedback is vital to education at all grades and kinds as a key element that provides information about whether or not the learning has taken place. The necessity and importance of the feedback is also valid for teaching practice (internship) in teacher training programs.

In this context, criticisms are being made in teacher observation and practice (internship) carried out in teacher training programs in Turkey that the PSTs have not 
received enough feedback or that they are not given feedback about their learning (Küçükyılmaz, 2010; Yeşilyurt \& Semerci, 2011; Kiraz, 2002; Aydın, 2013; Şen, 2009; Kuran, 2009; Peker, 2009; Koç \& Yıldız, 2012; Dallmer, 2004). In this study, it was aimed to determine the problems experienced in teaching practices by using PSTss' diary and observation forms in their teaching practices and to determine the effect of focus group discussions made for feedback purposes on the self-efficacy perceptions of PSTs, based on these diaries and observations.

It has been observed that self-efficacy perceptions of the PSTs in the experimental and control groups were similar in the sub-dimensions and total ; after the application, the PSTs in the experiment and control group had significant positive changes in the selfefficacy perceptions. According to this, it is determined that the teaching practice increases the self-efficacy perceptions of the PSTs even though different processes are carried out in the implementation process for them in the experimental and control groups. Some other studies in the literature (Görgen, Çokçalışkan, \& Korkut, 2012; Öksüz \& Coşkun, 2012, Cone, 2009; Şişman \& Acat, 2003) show that teaching practice is effective in raising self-efficacy perceptions of PSTs. The study found that, at the end of the 12-week study, there was a significant difference in favor of the experimental group between the increase in the self-efficacy perceptions of the PSTs in the experimental group in which the focus group discussions were conducted and the one in the control group in which these discussions were not carried out. According to this, the self-efficacy perceptions of the PSTs in the experimental group increased significantly at the end of the process compared to the PSTs in the control group. In other words, the increase in the self-efficacy perceptions of the PSTs in the experimental group in which the observation forms were filled and the diary was held and based on these, feedback group focus group discussions was applied, was significantly higher than in the control group which was subjected to teaching without these procedures. This finding suggests that focus group discussions have a significant effect in increasing self-efficacy perceptions, especially in the sub-dimensions of "providing student participation" and "learning strategies". This development observed in self-efficacy beliefs is expected to affect PSTs positively because teachers' high self-efficacy beliefs enable teachers to be able to do teaching effectively, to be effective in classroom management, and to be able to carry out the course in a planned manner.

In this research, the PSTs have stated that they have problems with classroom management, planning, teaching strategies, providing student participation. These findings regarding the problems faced by the PSTs in teaching practice are parallel to the findings of other researchers. In these studies, it has been determined that prospective teachers have difficulties in issues such as classroom management, time management, teaching strategies and planning (Ekiz, 2006; Şahin, Şenel, \& İpek, 2007; Güven, 2004; Işıkoğlu, İvrendi, \& Şahin, 2007;). In addition, in this study, it was determined that the prospective teachers increased the ability to recognize and express the problems they experienced in the course of teaching practice through focus group discussions, in other words, their level of awareness about these problems increased and they developed alternative solutions from a broader perspective, and conducted these solutions. In the general evaluation after the focus group discussions, the PSTs stated 
that the majority of these problems disappeared and that the discussions had positive contributions in the development of their teaching skills. This result suggests that feedback in the course of teaching practice is important for PSTs in acquiring teaching practices, in the promotion of teaching-related skills and self-efficacy perceptions.

\section{RECOMMENDATION}

The following recommendations can be highlighted for practitioners and researchers based the results concluded in this study.

- It is important that the teaching staff and the teachers at the school counseling the PSTs in the process of teaching practices give the candidates feedback about their own practices, the truths and deficiencies in the applications and provide the environments in which the candidates share the observations and thoughts about their own or their friends' practices.

- Such practices can be made not only for candidate teachers but also for teachers actively teaching. In this way, teachers also have the opportunity to discuss their lessons and discuss themselves.

- Further research is needed on the effectiveness of focus group discussions in teacher education. In this study, no method was tested in the control group. Subsequent similar studies can be compared with focus group discussions by applying techniques such as micro-teaching and extended micro-teaching in the control group. Or, focus group discussions can be made on the applications that only PSTs have observed, and the observations of prospective teachers can be discussed in this process. Also, The influence of focus group discussions on PSTs attitudes and thinking styles can be examined.

\section{REFERENCES}

Akşit, B. T. (1992). Medikal araştırmalarda etik sorunlar. Türk Tabipler Birliği Sağlık Kongresi. Ankara.

Aydın, İ. S. (2013). Mikroöğretim tekniğinin türkçe öğretmeni adaylarının planlama,uygulama ve değerlendirme yeterlik algılarına etkisi. Elektronik Sosyal Bilimler Dergisi, 12 (43), 67-81.

Büyüköztürk, Ş. (2009). Sosyal bilimler için veri analizi el kitabı. Ankara: Pegem

Büyüköztürk, Ş., Çakmak, E., Akgün, Ö.E., Karadeniz, Ş., \& Demirel, F. (2013). Bilimsel araştırma yöntemleri. Ankara: Pegem

Bowling, A. (2002). Research methods in health: Investigating health and health services. Philadelphia: McGraw-Hill House.

Cone, N. (2009). Community based service learning as source of personal self-efficacy: preparing elementary teachers to teach science for diversity. School Science and Mathematics, 109(1), 20-30. 
Çapa, Y., Çakıroğlu, J., \& Sarıkaya J. (2005). Development and validation of turkish version of teachers' sense of efficacy scale. Eğitim ve Bilim, 30, 74-81.

Dallmer, D. (2004). Collaborative relationships in teacher education: A per-sonal narrative of conflicting roles. Curriculum Inquiry, 34(1), 29-45.

Demircioğlu, İ. H. (2003). Tarih uygulama öğrencilerinin uygulama öğretmenleri ve uygulama okulları hakkındaki görüşleri: KTÜ eğitim fakültesi örneği. Fırat Üniversitesi Sosyal Bilimler Dergisi, 13(1), 185-192.

Dixon, B. J. (2009). A Formative Experiment Investigating The Use Of Reflective Video Journals To Increase High School Students' Metacognition. A dissertation submitted to the faculty of San Diego State University and the university of San Diego in partial fulfillment of the requirements for the degree doctor of education. San Diego State University. San Diego.

Ekiz, D. (2006). Kendini ve başkalarını izleme: Sınıf öğretmeni adaylarının yansıtıcı günlükleri. Illköğretim Online, 5(1), 45-57.

Görgen, İ., Çokçalışskan, H., \& Korkut. Ü. (2012). Öğretmenlik uygulaması dersinin öğretmen adayları, uygulama öğretmenleri ve uygulama öğretim üyeleri açısından işlevselliği. Muğla Üniversitesi Sosyal Bilimler Enstitüsü Dergisi, 28, 56-72.

Güven, İ. (2004). Sosyal bilgiler alanı öğretmen adaylarının okul uygulamalarına yönelik görüşlerine ilişkin nitel bir araştırma. Kuramdan Uygulamaya Eğitim Bilimleri Dergisi, 4(2).

Işıkoğlu, N., İvrendi, A., \& Şahin, A. (2007). Öğretmenlik uygulaması sürecine öğretmen adaylarının gözüyle derinlemesine bir bakış. Eğitim Araştırmaları, 26, 131142.

Karasar, N. (2005). Bilimsel araştırma yöntemi. Ankara: Nobel.

Kiraz, E. (2002). Öğretmen adaylarının hizmet öncesi mesleki gelişiminde uygulama öğretmenlerinin işlevi. Eğitim Bilimleri ve Uygulama Dergisi, 1(2), 183-196.

Kocabaş, A., Durukafa, G., \& Gürses, I. (2000). 1998-1999 Öğretim yılı güz yarıy1lı buca eğitim fakültesi uygulama okulları işbirliği programının uygulanmasında karşılaşılan sorunlar ve çözüm önerileri. D.E.Ü.Buca Ĕ̈itim Fakültesi Dergisi.

Koç, C., \& Yıldız, H. (2012). Öğretmenlik uygulamasının yansıtıcıları: Günlükler. Eğitim ve Bilim, 37, 164.

Krueger, R. A. (1994). Focus Groups: A Practical Guide For Applied Research. London: SAGE.

Kuran, K. (2009). Mikroöğretimin öğretmenlik meslek bilgi ve becerilerinin kazanılmasına etkisi. Mustafa Kemal Üniversitesi Sosyal Bilimler Enstitüsü Dergisi, 6 (11), 384-401. 
Küçükyılmaz, E. A. (2010). Sinıf öğretmenlerinin ögrretmenlik uygulaması dersi kapsamında öğretmen adaylarından beklentileri. 9.Sınıf Öğretmenliği Sempozyumu.

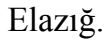

Lee, I. (2008). Fostering preservice reflection through response journals, Teacher Education Quarterly, 35(1), 117-139.

MEB Mevzuat (1998/2493). Öğretmen adaylarının Milli Eğitim Bakanlığına bağlı eğitim öğretim kurumlarında yapacakları öğretmenlik uygulamasına ilişkin yönerge. Tebliğler Dergisi, Retrieved from 30.05.2014 http://mevzuat.meb.gov.tr/html/102.html

Öksüz, Y., \& Coşkun, K. (2012). Öğretmenlik uygulaması I-II derslerinin zihin engelliler öğretmen adaylarının özyeterlik algılamaları üzerindeki etkisi. Ahi Evran Üniversitesi Kırşehir Eğitim Fakültesi Dergisi, 2(13), 131.

Özkılıç, R., Bilgin, A., \& Kartal, H. (2008). Öğretmenlik uygulaması dersinin öğretmen adaylarının görüşlerine göre değerlendirilmesi, İlkögretim-Online, 7(3), 726-737.

Peker, M. (2009). Genişletilmiş mikroöğretim yaşantıları hakkında matematik öğretmeni adaylarının görüşleri. Türk Eğitim Bilimleri Dergisi, 7(2), 353-376.

Şahin. Ç., Şenel, T. ve İpek, H. (2007, Eylül). Öğretmen adaylarının öğretmenlik uygulamalarında karşılaştıkları problemlerin belirlenmesi. XVI Ulusal Eğitim Bilimleri Kongresi, Gaziosmanpaşa Üniversitesi Eğitim Fakültesi, Tokat.

Şen, A.İ. (2009). Akran-mikro öğretimin öğretmen yetiştirme programındaki etkisinin araştırılması. Eğitim ve Bilim, 34, 151.

Şişman, M. ve Acat, B. (2003). Öğretmenlik uygulaması çalışmalarının öğretmenlik mesleğinin algılanmasındaki etkisi. Firat Üniversitesi Sosyal Bilimler Dergisi, 13(1), 235-250.

Yeşilyurt, E. ve Semerci, Ç. (2011). Uygulama öğretmenlerinin öğretmenlik uygulaması sürecinde karşılaştıkları sorunlar ve çözüm önerileri. Akademik Bakış Dergisi, 27.

Yıldırım, A. ve Şimşek, H. (2008). Sosyal bilimlerde nitel araştırma yöntemleri. Ankara: Seçkin Yayıncılı.

YÖK. (2007). Öğretmen yetiştirme ve eğitim fakülteleri (1982-2007) raporu. Ankara.

YÖK (1998). Eğitim fakülteleri öğretmen yetiştirme programlarının yeniden düzenlenmesi. Ankara. 


\section{Turkish Abstract \\ Odak Grup Tartışmalarının Öğretmen Adaylarının Öğretim Deneyimleri ve Uygulamaları Üzerindeki Etkisi: Karışık Yöntemler Çalışması}

$\mathrm{Bu}$ araştırmanın amacı, öğretmenlerin deneyim ve uygulamaları hakkında öz-yeterlik algısı üzerine odak grup tartışması yoluyla okul öncesi öğretmen adaylarına (PST) geribildirim sağlama etkisini araştırmak, öğretim uygulamaları sırasında karşılaşılan sorunları grup tartışması yaparak ve bu sorunların çözümüne yönelik öneriler geliştirmektir. Çalışma sonucunda, deney grubunda, odak grup tartışması okul öncesi öğretmenlerinin öz yeterlik algısı üzerinde belirgin ve olumlu bir etkiye sahip olduğu görülmüştür. Ayrıca, okul öncesi öğretmenlerle yapılan görüşmelerde, odak grup görüşmelerinin, ders planlama, sınıf yönetimi ve öğretim stratejileri gibi konularda ilerleme sağladığı belirtilmiştir.

Anahtar Kelimeler: okul öncesi öğretmenleri, odak grup görüşmesi, öz yeterlik algısı, öğretim etkinlikleri, geribildirim

\section{French Abstract}

L'Effet de Discussions de Groupe de discussion sur les Expériences d'Enseignement de Professeurs de Pré service et Pratiques: une Étude de Méthodes Mixte

Le but de cette étude est d'examiner l'effet de retour d'information fournissant pour pré entretenir les professeurs (PSTS) par la discussion de groupe de discussion sur la perception d'autoefficacité du PSTS' de l'enseignement d'expériences et des pratiques, déterminer des problèmes rencontrés pendant la pratique(le cabinet) enseignante au moyen de la discussion de groupe de discussion et développer des suggestions de la résolution de ces problèmes. En conséquence de l'étude, dans le groupe expérimental, la discussion de groupe de discussion a l'impact significatif et positif sur la perception d'auto-efficacité du PSTS'. De plus, dans des entretiens(interviews) avec PSTS, ils ont déclaré que la discussion de groupe de discussion leur a permis de faire des progrès dans des sujets comme la planification de leçon, la gestion(direction) de salle de classe et l'enseignement de stratégies.

Mots Clés: Pré entretenez des professeurs (PSTs), la discussion de groupe de discussion, la perception d'auto-efficacité, enseignant des pratiques, le retour d'information 


\section{Arabic Abstract}

تأثير مناقشات المجموعات البؤرية على الخبرات والممارسات التعليمية لمعلمي ما قبل الخدمة: دراسة طرق مختلطة

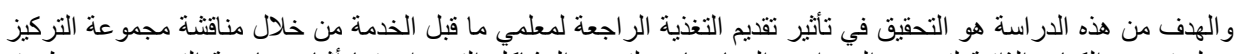



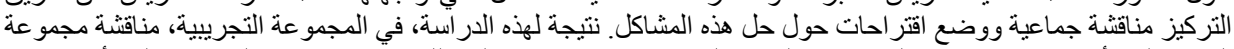



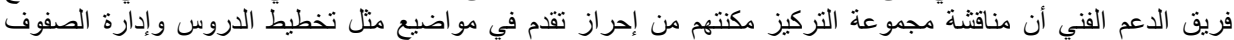
و واستر اتيجيات التدريس. الكلمات الرئيسية: المعلمين قبل الخدمة (PSTs)، مناقثة مجمو عة التركيز ، إدر الك الكفاءة الذاتية، و الممارسات

\section{German Abstract}

Die Wirkung von Fokus-Gruppe Diskussionen über Pre-Service-Lehrer 'Lehre Erfahrungen und Praktiken: Eine gemischte Methoden Studie

Das Ziel dieser Studie ist es, die Wirkung der Bereitstellung von Feedback an Pre-Service-Lehrer '(PSTs) durch Fokus-Gruppe Diskussion über PSTs Selbstwirksamkeit Wahrnehmung über Lehre Erfahrungen und Praktiken zu untersuchen, um Probleme zu ermitteln, die während der Lehrpraxis durch Fokus aufgetreten sind Gruppendiskussion und entwickeln Vorschläge zur Lösung dieser Probleme. Als Ergebnis der Studie hat die Fokusgruppen-Diskussion in der experimentellen Gruppe signifikante und positive Auswirkungen auf die SelbstwirksamkeitsWahrnehmung von PST. Darüber hinaus haben sie in Interviews mit PSTs festgestellt, dass die Fokusgruppen-Diskussion es ihnen ermöglicht, Fortschritte in Themen wie Unterrichtsplanung, Klassenzimmer und Lehrstrategien zu machen.

Schlüsselwörter: pre-service lehrer (PSL), fokus gruppendiskussion, selbstwirksamkeit wahrnehmung, lehrmethoden, feedback 


\section{Malaysian Abstract \\ Kesan Perbincangan Kumpulan Fokus pada Pengalaman dan Amalan Pengajar Pra- Perkhidmatan: Kajian Kaedah Campuran}

Tujuan kajian ini adalah untuk mengkaji kesan pemberian maklum balas kepada guru-guru praperkhidmatan (PST) melalui perbincangan kumpulan fokus mengenai persepsi keberkesanan diri PST tentang pengalaman dan amalan pengajaran, untuk menentukan masalah yang dihadapi semasa latihan mengajar dengan fokus perbincangan kumpulan dan buat cadangan tentang menyelesaikan masalah ini. Sebagai hasil kajian, dalam kumpulan percubaan, perbincangan kumpulan fokus mempunyai kesan yang signifikan dan positif terhadap persepsi keberkesanan diri PST. Selain itu, dalam temu bual dengan PST, mereka menyatakan bahawa perbincangan kumpulan fokus membolehkan mereka membuat kemajuan dalam topik seperti perancangan pelajaran, pengurusan kelas, dan strategi pengajaran.

Kata Kunci: guru pra-perkhidmatan (PST), perbincangan kumpulan fokus, persepsi keberkesanan diri, amalan pengajaran, maklum balas

\section{Russian Abstract \\ Эффект Дискуссий в Фокус-Группах по Опыт и Практике Преподавателей Пресервисных Учителей: Исследование Смешанных Методов}

Целью этого исследования является исследование влияния предоставления обратной связи преподавателям до начала обучения через дискуссию в фокус-группах по вопросу о самоэффективности преподавателей до начала обучения об опыте и практике полученного опыта, определение проблем, возникающих во время учебной практики, посредством обсуждения фокус-групп и разработку предложений по решению этих проблем. В результате исследования, в экспериментальной группе, обсуждение фокус-групп оказывает значительное и положительное влияние на восприятие самоэффективности преподавателей перед службой. Более того, в интервью с преподавателями, прошедшими предварительную службу, они заявили, что обсуждение в фокус-группах позволило им добиться прогресса по таким темам, как планирование уроков, управление классами и стратегии обучения.

Ключевые Слова: пресервисных учителей, обсуждение фокус-групп, восприятие самоэффективности, практика преподавания, отзывы 